\title{
Financial control in public service companies
}

\author{
Enier Caamaño ${ }^{\# 1}$, Raúl J. Martelo ${ }^{* 2}$, Natividad Villabona ${ }^{\$ 3}$

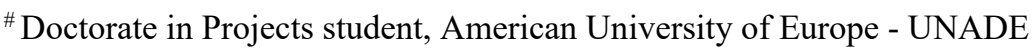 \\ 1enierc8@yahoo.com \\ * Faculty of Engineering, INGESINFO research group. University of Cartagena. \\ ${ }^{2}$ rmartelog1@unicartagena.edu.co \\ $\$$ Faculty of Economics Sciences. University of Cartagena. \\ ${ }^{3}$ nvillabonag@unicartagena.edu.co
}

\begin{abstract}
Financial control in public water utility companies was analyzed in the official sector of the Department of Cesar, Colombia. The research was descriptive, with no experimental, cross-sectional, field design. As a population, 20 subjects from three public service companies were selected. Deficiencies were found in the planning of resources, results and risks to carry out works. It is concluded that the companies studied do not always fulfill the functions of clarity, transparency, order and prediction of financial control.
\end{abstract}

Keyword - Planning, Efficient Administration, Internal Control, Aqueduct, Management

\section{INTRODUCTION}

Global trends in the globalization of the economy affect not only companies in the private sector directly, but also companies in the public sector, forcing them to revise or restructure their administrative models, as control and management tools that allow them to achieve high states of effectiveness in all its processes. In this sense, control is the process established to ensure that behavior and performance conform to the organization's standard. That is, financial and non-financial errors are verified and corrected to achieve the goals and objectives expected of the organization [1]. On the other hand, the global pressure on the control of corruption and the management of public funds is the main factor that requires the implementation of a good control system in all organizations, both private and public, at national, regional and local, to guarantee financial responsibility and transparency in the management of the fund at all levels [2].

In this sense, the control is considered to be a specifically human activity, consisting of permanent, real or periodic tests and analyzes of the information, processes or phenomena in a sector, office, service or determined area, with the aim of preventing or correct any deviation from the plan and that can address different challenges [3], for which there are knowledge and techniques that offer the possibility of better control and management of highly interconnected economic and financial systems and, therefore, can help to anticipate and manage future crises [4]. Therefore, by optimizing the operating processes of the entire company, performance management is achieved that is oriented to the operating process [5]. And the measurement of this performance, serves as a database to register a balanced activity through financial control [6].

On the other hand, it is crucial to have measurability of performance measures not only at the national level, but also in the international operations of a company, if you want to achieve a standardized regulation of key indicators in financial control to have a uniform control [7]. Therefore, the evaluation was carried out in accordance with the norms, policies and auditing procedures prescribed by the Comptroller General of the Department of Cesar, compatible with those of general acceptance. In this sense, some of the companies selected for the study do not have effective information systems, which is fundamental when it comes to evaluating internal control, management and budgeting. Likewise, lack of control is reflected in the financial statements, which is necessary to verify the correct application of generally accepted accounting principles, accounting standards, and different Colombian regulations with respect to tax laws.

Due to the above, it is necessary to analyze the Financial Control in Public Utility Water Supply Companies of the Official Sector in the Department of Cesar - Colombia. Because the proper analysis of financial control allows managers, specialists or not in the area, to control the finances of the organization, provide the necessary tools of the accounting system, to study the key structures that allow the proper development of it, and thus guarantee that the activities are carried out according to what is prescribed in the companies, together with the financial policies existing in the country of origin. 


\section{Methodology}

The present investigation is descriptive because the financial control variable was analyzed in public utility companies, describing their behavior as it happens [8]. Regarding the design, it was not experimental, field and cross-sectional, the non-experimental design is done without deliberately manipulating the variables [9], that is, a research where the determined phenomenon is observed. Similarly, in field design, information is collected directly in the place where the object of study is located [10]. Likewise, the cross-sectional or transversal design is the one in which the information is collected in a single moment, only once; whose purpose is to analyze a variety, as well as its incidence and interrelation in a given moment and space [9].

Regarding the study population, it was made up of the Public Services Aqueduct Companies of the Official Sector in the Department of Cesar - Colombia, which is classified as accessible and finite; in this sense, a total of three companies was selected, which are shown in Table I.

TABLE I. Population Distribution

\begin{tabular}{|c|c|c|}
\hline Aqueduct Public Utility Companies of the Official Sector & $\begin{array}{c}\text { Finance } \\
\text { managers }\end{array}$ & $\begin{array}{c}\text { Administrative- } \\
\text { accounting staff }\end{array}$ \\
\hline $\begin{array}{c}\text { Aqueduct and Sewer Public Services Company of the City of Valledupar } \\
\text { - EMDUPAR, S.A., ESP }\end{array}$ & 02 & 06 \\
\hline $\begin{array}{c}\text { Public Services Company of Aqueduct, Sewer and Toilet of Aguachica } \\
\text { E.S.P. }\end{array}$ & 02 & 06 \\
\hline Aqueduct and Sewerage Company of Curumaní, Cesar - Acuacur ESP & 02 & 02 \\
\hline Subtotal of subjects & 06 & 14 \\
\hline Total subjects & 20 key informants \\
\hline
\end{tabular}

The population census technique was applied because of the small number of representatives. No calculation was made after this specification to establish the study sample.

\section{A. Research instruments}

The process of data collection in this study was carried out using the technique of observation by means of a survey, [11] commenting that it uses tools, instruments or means, which are essential in socioeconomic research, such as the questionnaire and interviews. In this sense, the variable Financial control was measured, which was decomposed into 11 indicators that correspond to the different dimensions, by means of the application of a questionnaire-type instrument under a Likert-type measurement scale, which includes five alternative answers, Among which are: Always (A), Almost Always (AA), Sometimes (S), Almost Never (AN) and Never (N). Finally, it was made up of 33 items because three items were formulated for each indicator.

The instrument was subjected to a technical study to determine its validity, for which, a content validation instrument was developed, validated by five experts in the area of Financial Research and Control, which analyzed in detail the content and structure of the instrument, at the end of this process, the suggestions made were taken into account. In terms of reliability, a pilot test was applied to 10 subjects from a similar population and with the data obtained the Cronbach's Alpha coefficient was calculated. The result was 0.799, which is above 0.75 considered reliable.

\section{B. Data analysis}

The data obtained through the compilation of the information in this study, after applying the instrument, were tabulated and the techniques of descriptive statistics were applied: percentages of frequency and means. To facilitate the understanding of the data, the scale shown in Table II was designed.

TABLE II. Scale for Categorizing Scores in Results

\begin{tabular}{|c|c|c|c|c|c|}
\hline Alternatives & Never & Almost Never & Sometimes & Almost Always & Always \\
\hline Rank & $1-1.80$ & $1.81-2.60$ & $2.61-3.40$ & $3.41-4.20$ & $4.21-5$ \\
\hline Category & Inadequate & Moderately inappropriate & Little adequate & Moderately adequate & Adequate \\
\hline
\end{tabular}

\section{RESULTS}

The results of the investigation are presented below, in which the variable Financial Control in Public Utility Companies of Aqueducts of the Official Sector in the Department of Cesar - Colombia is examined. The analysis of the results obtained, based on the instruments applied to managers and administrative employees of the aforementioned companies, is presented in Table III (based on descriptive statistics). 
TABLE III. Analysis of results

\begin{tabular}{|c|c|c|c|c|c|c|c|c|c|c|c|c|c|c|}
\hline \multirow{2}{*}{ Indicators } & \multicolumn{2}{|l|}{ A } & \multirow{2}{*}{\multicolumn{2}{|c|}{\begin{tabular}{|l|l|} 
AA \\
Af & Rf
\end{tabular}}} & \multirow{2}{*}{\multicolumn{2}{|c|}{\begin{tabular}{|l|l|}
\multicolumn{1}{l}{ S } \\
Af & Rf \\
\end{tabular}}} & \multicolumn{2}{|c|}{$\mathrm{AN}$} & \multicolumn{2}{|l|}{$\mathrm{N}$} & \multicolumn{2}{|c|}{ Totals } & \multirow{2}{*}{$\mathrm{X}$} & \multirow{2}{*}{ Category } \\
\hline & Af & Rf & & & & & Af & $\mathrm{Rf}$ & Af & Rf & Af & Rf & & \\
\hline \multicolumn{15}{|c|}{ Dimension: Functions of Financial Control } \\
\hline $\begin{array}{l}\text { Efficient } \\
\text { Admin. }\end{array}$ & 7 & 33,3 & 6 & 31,7 & 4 & 20 & 2 & 11,7 & 1 & 3,3 & 20 & 100 & 3,8 & Mod. adequate \\
\hline $\begin{array}{l}\text { Reliability of } \\
\text { the financial } \\
\text { information }\end{array}$ & 5 & 26,7 & 7 & 33,3 & 4 & 18,3 & 3 & 15 & 1 & 6,7 & 20 & 100 & 3,58 & Mod. adequate \\
\hline Accountability & 9 & 43,3 & 6 & 28,3 & 2 & 11,7 & 2 & 10 & 1 & 6,7 & 20 & 100 & 3,92 & Mod. adequate \\
\hline X Dimension & \multicolumn{14}{|c|}{3,77} \\
\hline Category & \multicolumn{14}{|c|}{ Moderately adequate } \\
\hline \multicolumn{15}{|c|}{ Dimension: Types of Financial Control } \\
\hline $\begin{array}{l}\text { Immediate or } \\
\text { Directional } \\
\text { Control } \\
\end{array}$ & 8 & 41,67 & 4 & 21,67 & 2 & 10 & 4 & 18,33 & 2 & 8,33 & 20 & 100 & 3,7 & Mod. adequate \\
\hline $\begin{array}{l}\text { Selective } \\
\text { Control } \\
\end{array}$ & 8 & 41,67 & 5 & 25 & 4 & \begin{tabular}{|l}
16,6 \\
7 \\
\end{tabular} & 2 & 10 & 1 & 6,67 & 20 & 100 & 3,85 & Mod. adequate \\
\hline $\begin{array}{l}\text { Control } \\
\text { Posterior }\end{array}$ & 6 & 31,67 & 5 & 26,67 & 3 & \begin{tabular}{|l}
13,3 \\
3 \\
\end{tabular} & 4 & 18,33 & 2 & 10 & 20 & 100 & 3,52 & Mod. adequate \\
\hline $\mathrm{X}$ Dimension & \multicolumn{14}{|c|}{3,69} \\
\hline Category & \multicolumn{14}{|c|}{ Moderately adequate } \\
\hline \multicolumn{15}{|c|}{ Dimension: Stages of Financial Control } \\
\hline $\begin{array}{l}\text { Definition of } \\
\text { Future Results } \\
\end{array}$ & 5 & 25 & 6 & 28,33 & 5 & 25 & 2 & 11,67 & 2 & 10 & 20 & 100 & 3,47 & Mod. adequate \\
\hline $\begin{array}{l}\text { Determination } \\
\text { of Future } \\
\text { Objectives }\end{array}$ & 5 & 23 & 7 & 33 & 4 & 22 & 3 & 13 & 2 & 8,3 & 20 & 100 & 3,5 & Mod. adequate \\
\hline $\begin{array}{l}\text { Determination } \\
\text { of Flexible } \\
\text { Standards }\end{array}$ & 7 & 35 & 4 & 22 & 5 & 23 & 3 & 15 & 1 & 5 & 20 & 100 & 3,67 & Mod. adequate \\
\hline $\begin{array}{l}\text { Determination } \\
\text { of Information } \\
\text { Flows }\end{array}$ & 8 & 40 & 4 & 18,33 & 4 & $\begin{array}{l}18,3 \\
3\end{array}$ & 2 & 10 & 3 & 13,33 & 20 & 100 & 3,62 & Mod. adequate \\
\hline $\begin{array}{l}\text { Corrective } \\
\text { action } \\
\end{array}$ & 7 & 35 & 5 & 26,67 & 3 & \begin{tabular}{|l}
16,6 \\
7 \\
\end{tabular} & 3 & 15 & 1 & 6,67 & 20 & 100 & 3,68 & Mod. adequate \\
\hline X Dimension & \multicolumn{14}{|c|}{3,59} \\
\hline Category & \multicolumn{14}{|c|}{ Moderately adequate } \\
\hline
\end{tabular}

\section{A. Dimension: Functions of Financial Control}

Table I, for the indicator: Efficient Administration, indicates that the majority of respondents consider that the efficient administration of economic resources, managed by the companies under study, are being executed in a way that can be considered as fairly adequate. The above shows that there is a notable deficiency in that the planning of resources, results and risks is not always done to carry out the necessary works.

Regarding the analysis of the indicator: Reliability of Financial Information, according to the respondents, there are deficiencies in the accounting results, which prevents the transparency of financial reports in this regard. These aspects affect the reasonableness of the financial information and, therefore, in the trust and credibility before the interest groups.

With respect to the indicator: Accountability, in the companies studied occasional decisions are made related to the works to be executed without consulting or notifying previously the entities involved; nor is social control assumed as part of public management in the provision of public services of the aqueduct, sewerage and cleaning. 
In general, in the dimension: Functions of Financial Control, Public Utility Public Water Supply Companies in the Department of Cesar - Colombia, especially in the Companies of EMDUPAR S.A. E.S.P, E.S.P. of Aguachica and ACUACUR E.S.P., they have a notable deficiency due to the fact that resources, results and risks are not always planned to carry out the necessary works. These results differ from the findings in [12], which state that financial control reinforces the effectiveness and efficiency of institutions. In [13], it warns that innovation in the provision of services improves, the reduction of the cost of information and in [14], they specify that with the effective management of the functions of financial control, this guarantees the profitability of investments.

\section{B. Dimension: Types of Financial Control}

Regarding the indicator: Immediate or Directional Control, Table III indicates that this type of financial control is one of the most used in the companies studied. Likewise, a deficiency is evidenced due to the fact that foreseeable events are not always anticipated, for example, in the planning of costs there is no certainty in what should be done, if there are available resources or not and financial control of the processes is not carried out.

Regarding the indicator: Selective Control, it is observed that this type of financial control is also the most used in the companies studied. On the other hand, it was evident that financial control is not measured through its phases, financial operations are not always verified to measure their results and the process of such control is not resized, as a key aspect for its continuous improvement.

Regarding the indicator: Posterior Control, it is pointed out that this type of financial control is the least used by the companies under study. On the other hand, the weaknesses detected are mainly due to the fact that financial operations are not verified once the works have been completed to measure their results, nor are comparisons made between what was planned and what was actually executed, the correct measurement of the works executed and the investment made.

In general, for the Dimension: Types of Financial Control, the results show that of the types of control, the most used by the companies studied correspond to the indicators Immediate or Directional Control and Selective Control. These results agree with the findings of [15], where it was found that the control environment and a good system, is the basis of all components of internal control, provides the discipline and climate that influence the overall quality of internal control. In this sense, according to the cited author's approach, the application of a good financial control system allows the staff members of the organization, the verification of compliance with the procedures, and the adequate accounting record, as well as the financial management policies applied.

\section{Dimension: Stages of Financial Control}

Table III shows the behavior by indicator: of the Stages of Financial Control Dimension, which indicates that in the companies selected for the study, there are deficiencies in that an economic analysis of the company is not always carried out, prior to the projects to execute, to know its real situation, nor analyze the basic financial elements, not to fall into financial uncertainty later.

Regarding the indicator: Determination of Future Objectives, the results indicate deficiency in that it is not foreseen to avoid situations of supply of goods for the works to be executed for the provision of public services of the aqueduct, sewerage and cleaning.

Regarding the indicator: Determination of Flexible Standards, there are deficiencies regarding the standardization of patterns and policies to be executed for the effective fulfillment of the proposed objectives in the provision of public services of aqueduct, sewerage and cleaning.

On the other hand, for the indicator: Determination of Information Flows, the results indicate a deficiency by not applying standards and standardized policies in the different processes that impede the generation of reliable data about the operations performed in the provision of public services of aqueduct, sewage and toilet for the fulfillment of financial objectives.

According to the results of the corrective action indicator, there is a deficiency in the fact that financial corrective actions are not established in the light of the economic deviations arising in order to redirect the processes carried out or to review the usefulness to be perceived in the projects for the improvement of the benefit of the public services of aqueduct, sewerage and toilet.

In general, the Stages of Financial Control Dimension, the analysis indicates that the companies under study have a fairly adequate participation in relation to compliance with the indicators established in the stages of said control. The above results are not related to what was stated by [16], who asserts that financial control is a process that has as objective, on the part of the auditor, to know with certainty what is the real financial situation of the audited company. To this end, the auditor executes, in principle, as a first stage, an exhaustive analysis of the financial statements and the accompanying notes prepared by the company to be audited in relation to the operations carried out during a specific period. 
In the same way, the results are in contradiction with the approaches of [17], for whom financial control entails the verification or examination of financial, administrative, economic operations of an organizational entity, to establish that they have been carried out in accordance with the legal, regulatory and procedural norms that are applicable to them and that are required to be fully complied with by the State. On the other hand, the results are in agreement with the results of [18], where it was found that $78 \%$ of the companies carry out the planning activity as a substantive part of their work to manage the projects; while $100 \%$ said that it controls the execution of the projects.

\section{Summary of the behavior of the variable: Financial Control}

As shown in Table III, it is observed that the results are contradictory to what was passed by [19], who affirms that financial control is a key tool aimed at controlling the finances of the organization, by analyzing the structure of the accounting system and the internal accounting control. On the other hand, these results do not contrast with the contributions made by [20], where financial management indicators were identified for the control and monitoring of the activities of the companies examined, which conditions financial control for greater security in the policies adopted by companies today.

\section{CONCLuSION}

It is concluded that there are deficiencies in identifying the Functions of Financial Control in Public Utility Water Supply Companies of the Official Sector in the Department of Cesar - Colombia, because the reliability of the presentation of the financial statements, its clarity and transparency is not estimated, in breach of applicable laws and regulations. Likewise, it is concluded that the immediate or directional financial control is applied, in order to know almost with certainty what will happen in a certain period, allowing the corrective action to be carried out easily.

Regarding the stages of Financial Control, it is concluded that they are met with certain deficiencies, because they are not always clearly defined, what are the desired results. Finally, it is concluded that the Financial Control implemented in the companies studied have deficiencies in their Dimensions, as managers and finance managers do not conceive it as a key tool to control finances, evaluate the structure of the accounting system and of the internal accounting control, as well as, to determine if the activities, the records of the transactions of the economic events that take place in the companies, are in accordance with the applicable financial policies and standards.

\section{REFERENCES}

[1] A. Kazmi, Business policy and strategic management, 3th edition. New Delhi: Tata McGraw-Hill Publishing Company Limited, 2008.

[2] S.F Aramide and M.M. Bashir, "The effectiveness of internal control system and financial accountability at Local Government level in Nigeria", International Journal of Research in Business Management, vol. 3, no. 8, 2015.

[3] I.G. Popa and N.L. Nasta, "Study on the Public Financial Control in Romania", Land Forces Academy Review, vol. 21, no. 1, pp. 77, 2016.

[4] S. Battiston, J.D. Farmer, A. Flache, D. Garlaschelli, A.G. Haldane, H. Heesterbeek and M. Scheffer, "Complexity theory and financial regulation", Science, vol. 351, no. 6275, pp. 818-819, 2016.

[5] M. Bititci, P. Garengo, V. Dörfler and S. Nudurupati, "Performance Measurement: Challenges for Tomorrow", International Journal of Management Reviews, vol. 14, pp. 305-327, 2012.

[6] R. Gleich, Performance Measurement: Konzepte, Fallstudien und Grundschema für die Praxis, 2nd edition. München: Springer, 2011.

[7] A. Neely, "The Evolution of Performance Measurement Research - Developments in the Last Decade and a Research Agenda for the Next”, International Journal of Operations and Production Management, vol. 25, pp. 1264-1277, 2005.

[8] M.D. Gall, J.P. Gall and W.R. Borg, Educational research: An introduction, 8th edition. Boston: Pearson, 2007.

[9] R. Hernández, C. Fernández and P. and Baptista, Metodología de la investigación, 5th edition. México: McGraw-Hill Interamericana, 2010.

[10] W. Artigas and M. Robles, "Metodología de la investigación: Una discusión necesaria en Universidades Zulianas", Revista Digital Universitaria, vol. 11, no. 11, pp. 1-17, 2010.

[11] A. Bavaresco, Proceso Metodológico en la Investigación. Cómo hacer un diseño de investigación. Venezuela: Universidad del Zulia, 2008.

[12] A.D. Ahmed, "Effects of financial liberalization on financial market development and economic performance of the SSA region: An empirical assessment", Economic Modelling, vol. 30, pp. 261-273, 2013.

[13] F. Islam, M. Shahbaz, A.U. Ahmed and M.M. Alam, "Financial development and energy consumption nexus in Malaysia: a multivariate time series analysis", Economic Modelling, vol. 30, pp. 435-441, 2013.

[14] M. Shahbaz and H.H. Lean, "Does financial development increase energy consumption? The role of industrialization and urbanization in Tunisia", Energy policy, vol. 40, pp. 473-479, 2012.

[15] L.R. Hurloiu, E. Burtea and B.F. Preda, "Organizing inspections regarding managerial internal control and preventive financial control", Procedia Economics and Finance, vol. 16, pp. 275-280, 2014.

[16] R. Vilches, Apuntes del estudiante de Auditoría, Contador General mención Computación. Universidad Católic, 2005.

[17] A.C. Ruiz, Auditoria financiera. Mexico: Revista del Coloquio sobre Cultura, 2011.

[18] J.A. González, R. Solís and C. Alcudia, "Exploratory Study on Project Planning and Control for Small and Medium Size Construction Firms", Revista de la Construcción, vol. 9, no. 1, pp. 17-25, 2010.

[19] G. Castaño, Concepto de Control, in Seminario de Teoría Administrativa, Faculty of Management. National University of Colombia, 2005.

[20] D.J. Márquez, Gestión financiera de los institutos autónomos adscritos a la Alcaldía del Municipio Maracaibo del Estado Zulia. Venezuela: University of Zulia, 2011. 


\section{AUTHOR PROFILE}

Enier Caamaño works as independent researcher. Mr. Caamaño completed his undergraduate in Public Public Accounting at San Martín University Foundation.

Raul J. Martelo works as full-time professor at the University of Cartagena (Colombia). Mr. Martelo completed his magister from Industrial University of Santander (Colombia). Mr. Martelo completed his undergraduate in Systems Engineering at the Industrial University of Santander.

Natividad Villabona works as full-time professor at the University of Cartagena (Colombia). Mrs. Villabona completed his magister from Technologic University of Bolivar (Colombia). Mrs. Villabona completed his undergraduate in Industrial Engineering at the Industrial University of Santander. 